\title{
Н.Л. Зелянская
}

Алтайский государственный университет

\section{Основные семиотические тенденции прозы 40-х годов XIX века}

Эпоха 40-х годов XIX века представляет собой знаковый этап в развитии русской литературы, т.к. этот культурно-исторический период объединяет в динамическую целостность художественно-семиотические тенденции предшествующей поры (связанные, прежде всего, с романтизмом, эстетикой декабристов и творчеством А.С. Пушкина) и зарождающиеся литературные процессы (реализовавшиеся во второй половине века). На знаковую недифференцированность литературно-художественной реальности данного десятилетия, прежде всего, указывают многочисленные философско-эстетические споры, которые велись тогда за идеологическое первенство между западниками, славянофилами, революционными демократами, а также иными течениями, занимавшими не столь ортодоксальные позиции. Именно ощущение культурноисторического «перепутья» заставляет активных участников общественной и культурной жизни России 1840-х годов искать, предлагать и оспаривать все новые и новые концепции героя, характерологии, способы организации пространства произведения, художественные приемы.

Этот временной отрезок исследователи традиционно определяют как границу, которая разделяет разные культурно-исторические этапы, разные доминантные смысловые интенции, но сам, скорее, характеризуется неопределенностью и полипотенциальностью. Особое положение 1840-х годов как периода становящегося динамического семиозиса позволяет сделать предположение о том, что изучение актуальных смысловых тенденций в текстах, порожденных интересующим нас временем, позволит создать модель, в которой было бы отражено соотношение и взаимодействие данных тенденций на указанном эпохальном срезе ${ }^{1}$. В нашей работе осуществлена попытка построения такой интегрирующей модели, репрезентирующей сложность семиотической динамики, характерной для изучаемого нами переходного десятилетия. В основу модели легли результаты компонентного анализа заглавий прозаических произведений, написанных и / или напечатанных в 40-е годы XIX века, иерахизированные с помощью статистических методов.

Выбор заглавий в качестве материала, репрезентирующего семиотические интенции эпохи, не случаен, т.к. основная функция, выполняемая этим рамочным компонентом любого текста, - «раскрытие самой важной темы» произведения [Выготский, 1998, с. 202]. Отметим также, что заглавие всегда представляет текст во внешнем мире, а значит, репрезентативная выборка заглавий, номинирующих произведения какого-либо периода времени, становится объективным выразителем «сущности» [Тюпа, 2001, с. 115] этого времени, и соответственно, является важным материалом для определения характерных для него векторов семиозиса. Именно поэтому даже в случае, если заглавие кардинально переосмысляется по отношению к самому тексту (вплоть до противоположности

${ }^{1}$ Подробнее о соотношении модели и репрезентируемой действительности см.: [Штофф, 1966]. 
семантики, как это бывает в произведениях с доминирующим модусом комического), запечатленные в нем семы в общем контексте эпохи, даже через отрицание, не теряют своей презентативности и актуальности.

В нашем исследовании мы останавливаемся только на заглавиях прозаических произведений художественного творчества (романов, повестей, рассказов) и тех прозаических жанров, которые, занимая промежуточное место между художественной и нехудожественной прозой, с 40-х годов XIX века начинают приобретать статус художественной литературы (имеются в виду очерки, мемуары): их можно считать периферийными компонентами художественного дискурса. Литературно-критические статьи, научные статьи и диссертации не рассматривались, поскольку они являются частью кардинально иного дискурсивного пространства; заглавия же поэтических произведений были исключены, поскольку с 1840-х годов начинается явное доминирование прозаических жанров, поэзия же значительно уступает и в количественном, и в качественном отношении (ярких имен в поэтическом творчестве этого периода немного).

Для анализа мы отобрали все заглавия прозаических произведений 1840-х годов, упомянутые в биобиблиографическом словаре «Русские писатели» под редакцией П.А. Николаева [Русские писатели, 1990]. В данном словаре представлены статьи о 125 литераторах разной степени значимости, творческая деятельность которых осуществлялась в интересующую нас эпоху. В центре нашего внимания оказалось 221 заглавие. Таким образом, материал для анализа мы отобрали путем исчерпывающей сплошной выборки из совокупности, составленной авторами словаря по аксиологическому принципу, т.е. так, чтобы творчество каждого писателя было представлено наиболее репрезентативными произведениями. То обстоятельство, что в нашу выборку вошли заглавия наиболее важных для истории литературы произведений, а также то, что творческое наследие интересующих нас писателей принадлежат к разным ценностным рядам, свидетельствует о достоверности результатов (проанализированная выборка адекватно отражает генеральную совокупность заглавий, номинирующих прозаические произведения 40-х годов XIX века).

Алгоритм исследования был продиктован логикой разработанного нами (совместно с К.И. Белоусовым) метода графосемантического моделирования, которому предшествовал ряд филолого-семиотических и статистических процедур. Графосемантическое моделирование представляет собой метод графической экспликации структурных связей между семантическими компонентами одного множества ${ }^{1}$. В нашем случае исследуемое множество образовали семантические компоненты, выделенные нами в процессе компонентного анализа каждого заглавия выборки. Связи между этими компонентами обусловлены их реальным соединением в семантическом пространстве заглавия.

В целом, предварительные процедуры, необходимые для построения графосемантической модели, можно представить в виде следующих шагов:

1. В каждом заглавии выделяется некоторый набор сем, содержащихся в лексеме (лексемах), составившей это заглавие. Например, в названии рассказа

1 Более подробно о методе графосемантического моделирования см.: [Белоусов, Зелянская, 2005б; Белоусов, Зелянская, 2005в]. Данный метод имеет широкое поле приложения. Он является продуктивным для решения проблем, связанных с семантикой объектов разной природы. Метод был апробирован нами при исследовании функционирования системы литературоведческих категорий в рецептивных пространствах учительского и филологического микросоциумов [Зелянская, 2005а; Зелянская, 2005в], при анализе культурных фактов [Зелянская, 2005б; Зелянская, Белоусов, 2006], в лингвомаркетологических исследованиях [Белоусов, Зелянская, 2005а и т.п.]. 
Ф.М. Достоевского «Господин Прохарчин» (1846) содержатся такие семантические компоненты: говорящая фамилия (в лексеме Прохарчин), бедность (в лексеме Прохарчин), голод (в лексеме Прохарчин), еда (в лексеме Прохарчин), социальная характеристика (в лексеме господин), высшее общество (в лексеме господин), власть (в лексеме господин), отношения с людьми (в лексеме господин), иентрализация вокруг героя (в обеих семах заглавия), мужское (в обеих семах заглавия). Таким образом, мы проанализировали 221 заглавие, в итоге было выделено 1600 сем.

2. Полученные семантические компоненты по общим основаниям группируются в семантические поля. Например, компоненты лес, река, скаль, берег, болото, водоем объединены нами в поле «природное пространство». В целом, после объединяющей процедуры было сформировано 40 полей.

3. Определяется количество связей между полями, для чего выявляется общее количество взаимодействий, которое образует каждое поле с другими полями в рамках семантического пространства каждого заглавия.

Значимостью для характеристики культурно-семиотического пространства 1840-х годов, конечно, обладают не все семантические поля и не все связи, образованные ими. Семантические связи, достаточной силы, т.е. силы, преодолевшей статистический порог значимости ${ }^{1}$, обнаружили 22 семантических поля, статистически значимой частотностью обладают 8 полей (все частотные поля оказались способными образовывать сильные семантические связи с другими полями). Способность поля образовывать значимые связи (иначе валентность поля) говорит о его семантической активности, т.е. о том, как часто компоненты этого поля вступают в ассоциативно смысловое взаимодействие с компонентами других полей, образуя непрерывность семиотического пространства эпохи; показатель частотности поля свидетельствует о том, как часто это поле встречается в выборке.

В целом полученная графосемантическая модель отражает сложные отношения между всеми компонентами культурно-семиотической системы прозы 1840-х годов. Соотношение показателей встречаемости и валентности обнаруживает детерминирующее влияние центрального поля - репрезентанта основных семиотических тенденций, а также конфликтующие с ним тенденции, связанные с альтернативными доминантами. Несколько подчиненную роль играют периферийные и тупиковые поля, выполняя функции уточнения векторов развития семиозиса и границы самотождественности системы.

В данной статье мы рассматриваем только доминирующий элемент графосемантической модели, которым является поле «организация произведений» (второе по встречаемости и первое по валентности). Содержательное наполнение этого поля составили компоненты, связанные со способами расположения фактов, элементов повествования, персонажей, со спецификой протекания действия, композиционными рамками и отступлениями. Так, заглавия «Антон Горемыка» (Д.В. Григорович, 1847), «Господин Прохарчин» (Ф.М. Достоевский, 1846) и т.п. указывают на то, что все повествовательные блоки произведений расположены вокруг одного образа и подчинены, прежде всего, логике его раскрытия; в «Мемуарах Мякушкина» (Г.Ф. Квитка, 1841) и «Моих курских знакомцах» (М.С. Жукова, 1840) открывается важная роль повествователя, определяющая способы изложения материала, построение характеров персонажей; заглавия же типа «Неоконченные повести» (В.А. Соллогуб, 1843), «Путевые впечатления и, между прочим, горшок герани» (А.Ф. Вельтман, 1843) акцентируют внимание на специфике литературного творчества, структурировании художественного пространства (в частности, на отсутствии финальной эстетической границы), на 1980].

${ }^{1}$ Подробнее о статистической обработке данных см. [Гласс, Стэнли, 1976; Лакин, 
самом течении действия (наличие отступлений от темы, о чем сигнализирует вводная конструкция «между прочим»).

На рисунке 1 представлен фрагмент графосемантической модели культурносемиотического пространства прозы 1840-х годов, отражающий валентное пространство доминантного поля. В рамках реконструированной семиотической системы данное поле образует максимальное количество связей, поэтому неоднородность отношений «организации произведений» с другими полями можно считать репрезентативным отражением отношений внутри системы вообще.

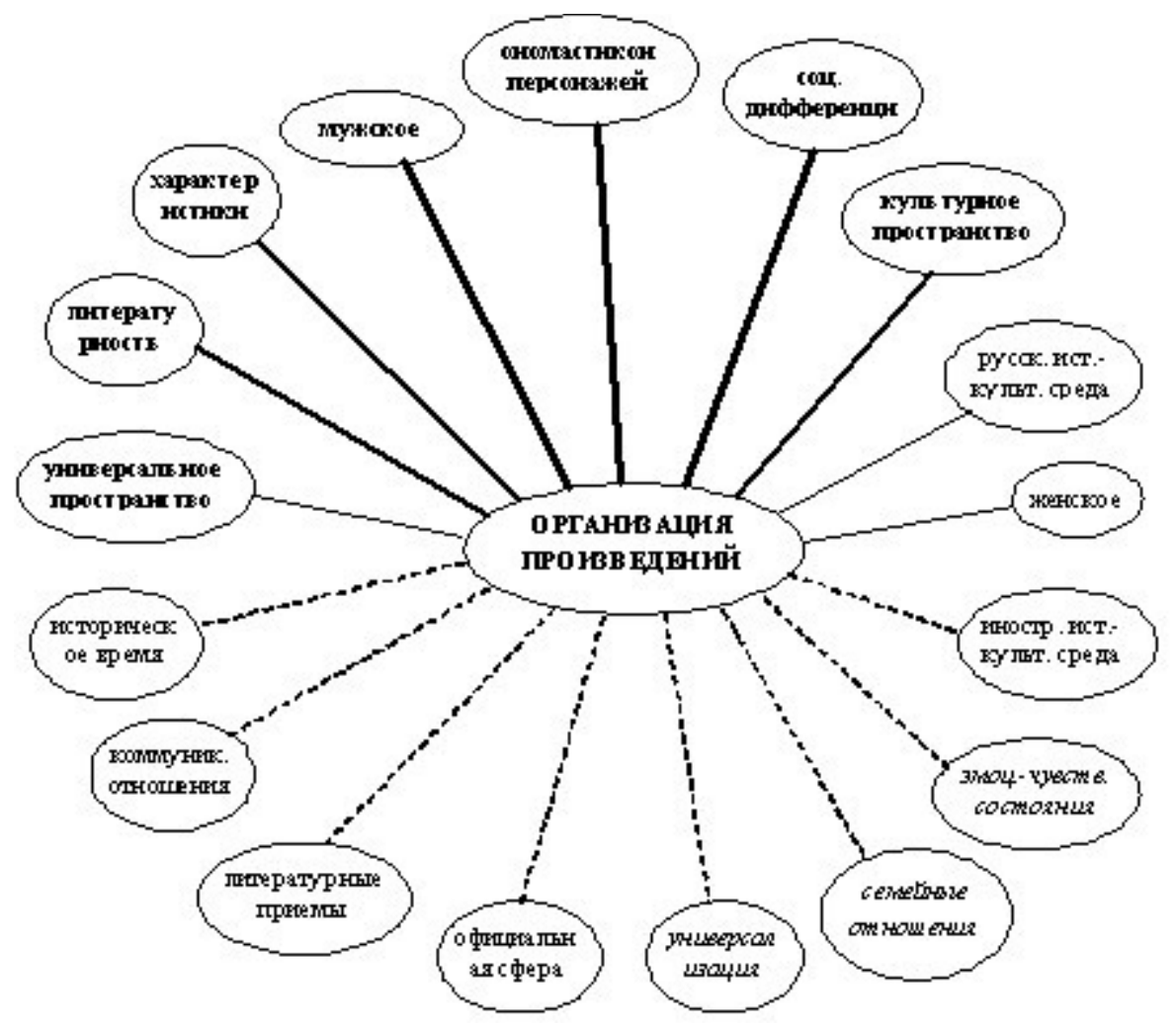

Рисунок 1. Семантические связи поля «организация произведений»

Примечание. На рисунке приняты следующие сокращения «сочиальная дифференциачия» - «сои. дифференцииачия»; «межличностно-коммуникативные отношения» - «коммуник. отношения»; «русская историко-культурная среда» - «русск. ист.-культ. среда»; «иностранная историко-культурная среда»- «иностр. ист.-культ. среда»; «эмоционально-чувственные состояния» - «эмоч.-чувств. состояния»; «мужсккое начало» - «мужское»; «женское начало» - «женское». Прописными буквами на рисунке обозначено доминантное поле системы. Жирным ирифтом - альтернативные доминанты, обычным шрифтом - периферийные, курсивом - тупиковые компоненты системы. Пунктирными линиями отмечены связи, сила которых превымает статистический порог значимости, равный среднее+б; обычными линиями обозначены связи, сила которых превышает среднее+2б; полужирными линиями обозначены связи, сила которых превымает среднее+3б; жирными линиями обозначены связи, сила которых превышает среднее $+4 \sigma$ и более.

C позиции дифференциации по эстетическим направлениям указанное семантическое поле совершенно нейтрально, способы построения произведения 
выступают не в качестве основания для противопоставления художественных установок, а обнаруживают преемственность культурного пространства 1840-х годов с философско-эстетическими идеалами гуманизма всего Нового времени, помещающими человека в центр мироздания. Проецируя данный вывод на семиотическое пространство прозы 40-х годов XIX века, можно отметить, что парадоксальным образом, в эпоху, открывающую большие литературноидеологические споры, в качестве незримого единящего фактора начинает выступать универсальный принцип, акцентирующий внимание на организации художественного мира (главным образом, вокруг человеческой личности) и на утверждении законов этой организации. Таким образом, в центре семиотической системы прозы 1840-х годов оказываются принципы художественной онтологии.

Поля, вошедшие в валентное пространство доминантного элемента системы, позволяют уточнить актуальные для исследуемой эпохи онтологические черты художественной реальности, представленной в произведениях, и самого процесса художественного творчества. Наиболее сильные семантические связи (см. рисунок) доминантное поле образует с «ономастиконом персонажей», «социальной дифференциацией» и «мужским началом».

Поле «ономастикон персонажей» включает в себя имена, фамилии, отчества и прозвища героев, т.е. указывает на важность факта индивидуального бытия того или иного персонажа, выделяет его из ряда подобных. Ономастикон является также и характеристикой называемого героя - традиция «говорящих» фамилий, идущая еще из поэтики классицизма, наличие / отсутствие отчества, значение имен, сочетаемость имени и фамилии и тому подобные детали становятся семиотическим основанием для обозначения личного пространства персонажа. В качестве примера ономастических заглавий можно привести «Майор Смагин» (Н.С. Кохановская, 1844) (акцент на фамилии - родовом единстве - в совокупности с чином уменьшает значимость личного начала, переориентируя образ в сферу социума); «Полинька Сакс» (А.В. Дружинин, 1847) (на первый план выходит субъективно-личностное начало, сфера эмоций); «О том, кто такой был Елпидифор Перфильевич и какие приготовления делались в городе Чернограде к его именинам» (П.И. Мельников, 1840) (имя и отчество, свидетельствующие о солидности персонажа, одновременно, его профанируют, создавая комический фон путем сочетания звуков) и т.п.

Поле «социальная дифференциация» объединяет семы, связанные с разными проявлениями сословной принадлежности, причем в выборке не было предпочтено какое-либо одно сословие или какой-либо один способ обозначения социального статуса. Например, в заглавии «Бедные люди» (Ф.М. Достоевский, 1846) опосредованно, через указание на материальное положение, показана принадлежность персонажей к низшим ступеням социальной лестницы; подчеркнутая незнатность героя может присутствовать в его ономастическом облике - «Жизнь и похождения Петра Степанова сына Столбикова» (Г.Ф. Квитка, 1841); в заглавиях «Ольга. Быт русских дворян в начале нынешнего столетия» (Д.Н. Бегичев, 1840), «Пан Халявский» (Г.Ф. Квитка, 1840) содержится прямое указание на высшее сословие; социальный статус через профессиональную принадлежность обнаруживается в заглавиях типа «Доктор» (Е.П. Гребенка, 1844), «Петербургские шарманщики» (Д.В. Григорович, 1845) и т.д.

Поле «мужское начало» предполагает конкретную половую отнесенность и, вместе с тем, гендерные стратегии поведения; «мужское начало» не просто преобладает в выборке над противоположным по гендерному основанию полем, мужской персонаж практически становится семиотическим синонимом литературного персонажа как такового, что свидетельствует о своеобразном «Гендерном крене» всей реконструируемой культурно-семиотической системы. (Поле «женское начало» образует связи, преодолевшие статистический порог 
значимости, но не является частотным в выборке.) Семы этого поля явно присутствуют в заглавиях «Казак Трофим» (М.Л. Михайлов, 1845), «Два старичка» (М.М. Достоевский, 1849), «Записки студента» (Е.П. Гребенка, 1841) и т.д.

Несколько меньшую степень значимости имеют связи, которые ядерный компонент системы образуют с полями «культурное пространство», «характеристики» и «литературность». Данные поля также находятся в сильной позиции, поэтому формируемый ими, по преимуществу, деятельностноаксиологический, контекст приобретает ценность для понимания доминантной категории системы.

Сильная семантическая связь поля «организация произведения» с «литературностью» (первым по частотности и вторым по количеству образованных сильных связей), на наш взгляд, симптоматична. Данное поле составили компоненты, указывающие на словесную природу бытования состоявшегося произведения искусства, на принадлежность его к литературному жанру, установку на коммуникативную ситуацию, предполагающую записывание и последующее чтение.

Так, заглавия «Рассказ Алексея Дмитрича» (1848), «Роман в записках» (С.Ф. Дуров, 1847), «Дорожные записки на пути из Тамбовской губернии в Сибирь» (П.И. Мельников, 1839 - 1841) и т.п. одновременно определяют жанровую принадлежность называемого произведения и подчеркивают процесс писания или рассказывания, т.е. нарративного преобразования реальной действительности в литературно-художественную. Семы поля «литературность» могут также присутствовать посредством упоминания составляющих художественного произведения («Маленький герой» (Ф.М. Достоевский, 1849): одно из значений слова «герой» - литературный персонаж) или «вплетаясь» в ономастический облик действующего лица («Неточка Незванова» (Ф.М. Достоевский, 1849): фамилия героини содержит корень, обозначающий речевое действие, что является знаковым в контексте художественной реальности).

Признание системой важности способов и форм организации художественного мира как основных онтологических принципов влечет за собой рефлексию над феноменом литературности - совокупности процесса и результата словесного художественного творчества. Поле «литературность» включает в процесс семиозиса 40-х годов ХІХ века саму литературную деятельность, проблема писательства в эти годы становится важным предметом художественных произведений.

Поле «культурное пространство» образовано компонентами, представляющими собой эстетические категории и установки в их связи с культурно-историческим процессом, т.е. семами, которые создают историческую, культурологическую, межкультурную, эстетическую перспективу, такими, как модус и пафос, аллюзивная или непосредственная отнесенность к какому-либо культурно-историческому периоду, эстетическому направлению, иным видам искусства и т.п. Например, заглавия «Народные сказания о кладах, разбойниках, колдунах и их действиях, записанные в Малоархангельском уезде» (П.И. Якушкин, 1844), «Быль не быль и сказка не сказка» (Е.П. Гребенка, 1844) открывают фольклорно-мифологический контекст, с акцентом на русской культуре, причем второе заглавие, определенно, имеет ироническую модальность. Мифологические коннотации присутствуют и в заглавиях «Актеон» (И.И. Панаев, 1842), «Черный демон» (М.С. Жукова, 1840), «Вакх Сидоров Чайкин» (В.И. Даль, 1843 ), соединяясь и с романтической эстетикой («Черный демон»), и с пуантическим смешением возвышенно-благородного и комического модусов («Вакх Сидоров Чайкин»). 
Мы считаем, что соотнесенность «организации произведения» и «культурного пространства» обусловлена стремлением системы «вписать» себя в более широкий контекст аналогичной природы. Рефлексия по поводу онтологических принципов художественного мира именно в общекультурном, общеэстетическом пространстве открывает ряды парадигматических установок, способных стимулировать становление художественного мира. Данные установки (от мифологии до современности) определяют необходимое метапространство функционирования, интертекстуальной коммуникации и самоидентификации прозы 40-х годов XIX века как семиотического события, а также привносят дополнительные основания для организации собственного художественного пространства и поиска новых конструктивных художественных энергий.

Семантическая связь доминантного поля с полем «характеристики» выводит на первый план акт оценивания как указание на организующую волю порождающего художественную реальность сознания. Поле «характеристики» составили компоненты, представляющие собой разнообразные явные и имплицитно присутствующие характеристики и оценки, конкретное наполнение которых не обобщается в самостоятельные блоки, а значит, оказывается семиотически не важным в контексте исследуемой эпохи. Примерами разнообразия оценочно-характеризующих заглавий могут послужить «Сердешна Оксана» (Г.Ф. Квитка, 1841), «Сорока-воровка» (А.И. Герцен, 1846), «Странная история» (Я.П. Бутков, 1849), «Темный человек» (Я.П. Бутков, 1848), «Чужое дитя» (С.Ф. Дуров, 1846).

Таким образом, в рамках семиотического пространства прозы 1840-х годов активным структурирующим началом становится обобщенный источник некоторых интенций, полемичный, с подвижными ценностными установками (видимо, в силу их эпохального разнообразия), который, на наш взгляд, может персонифицироваться либо в авторе-экспериментаторе, либо в виде повествователя, рассказчика, литературной маски.

Еще один блок семантических полей, отражающих специфику художественной онтологии 40-х годов XIX века, имеет среднезначимую (см. рисунок) силу связи с «организацией произведений», это - «универсальное пространство», «русская историко-культурная среда» и «женское начало». Из них только поле «универсальное пространство» является сильным по частотности и валентности. Компоненты данного поля предполагают дифференциацию мира по общепринятым пространственным категориям (свое / чужое, направление пути, границы / их отсутствие), а также указание на наличие пространства как такового через обозначения территориальной приуроченности, некоторого ландшафта и т.П. Подобное пространство обладает повышенной семиотичностью и склонностью к символизации.

Семы данного поля могут быть представлены в заглавиях и как непосредственная презентация некоторого масштабного пространства, и опосредованно, как осмысление человеческой жизни в пространственных категориях. Например, «Три страны света» (Н.А. Некрасов, А.Я. Панаева, 1848 1849) является прямым обобщенным указанием на три направления в пространстве, открывающие ущербность (не четыре, а три «страны») мира; заглавия же «Театральная карета» (Д.В. Григорович, 1844), «Жизнь и похождения Петра Степанова сына Столбикова» (Г.Ф. Квитка, 1841) и т.П. позволяют соотнести жизненный путь и передвижение в пространстве как символические аналоги.

Поле «русская историко-культурная среда» можно считать в рамках целой семиотической системы одним из компонентов-конкретизаторов, оно формирует национальный контекст для процесса смысловой организации пространства прозы 40-х годов XIX века. Компоненты смысла, актуализирующие причастность к 
русской культуре, обнаруживаются в заглавиях «Русские ночи» (В.Ф. Одоевский, 1844), «Русский мужик» (В.И. Даль, 1845), «Господин Светелкин» (М.М. Достоевский, 1848) и т.п.

Периферийный статус данного поля (см. рисунок) свидетельствует о том, что оно не играет самостоятельной роли в общем процессе семиозиса эпохи. Достаточно сильная связь поля «русская историко-культурная среда» с доминантой позволяет утверждать, что русская тема участвует при создании художественного мира, но не акцентуируется, экзальтически не заостряется, как это бывает, например, в периоды национальной беды, противостояния с другими нациями или необходимости национальной самоидентификации. Это поле, скорее, является стабильным естественным семиотическим фоном для реализации более активных с точки зрения становления художественной онтологии сем.

На латентную, потенциальную значимость (в изучаемый период времени явно нейтрализованную) русской темы указывает и небольшое влияние присутствующего в системе противоположного поля «иностранная историкокультурная среда». Так, заглавия «Полинька Сакс» (А.В. Дружинин, 1847), «Жюли» (А.В. Дружинин, 1849), «Панна Сотникова» (Г.Ф. Квитка, 1840), очевидно, включают в себя семы этого поля. Сама оппозиция «русское / иностранное» создает интригу противо-сопоставления, но (возможно, парадоксальная ситуация в контексте ожесточенных споров о судьбах России, деления на западников и славянофилов и т.п.) данная интрига не является конфликтом. В рамках системы указанные поля соотносятся друг с другом только опосредованно, через доминанту, т.е., по сути, «растворяются» в ней. Так, противостояние культур в пространстве прозы 40-х годов XIX века становится частью эстетически значимого поведения, игры, направленной на реализацию творческого акта (организацию произведения), но не выходит за рамки художественно-идеологической сферы.

Последнюю среднезначимую валентную зависимость «организация произведения» образует с полем «женское начало». Данное поле (при малой роли в семиотической системе прозы 40-х годов XIX века) оказалось способным образовать достаточно сильную связь с доминантой, что обнаружило его нарастающий семиотический потенциал. Семы поля «женское начало» присутствуют и как нейтральное указание на женского персонажа («Нина» (А.Ф. Писемский, 1848)), и как знаки причастности к эмоциональному миру («Варенька» (М.В. Авдеев, 1849 - 1851)), к миру семейных отношений («Дочка» (М.М. Достоевский, 1848), «Воспитанница» (В.А. Соллогуб, 1845)), и через сословно-социальные маркеры («Аптекарша» (В.А. Соллогуб, 1841), «Графиня Д» (Н.С. Кохановская, 1848)), и даже как семиотические составляющие образа мужского персонажа («Записки Тамарина» (М.В. Авдеев, 1849 - 1851)).

О явном потенциале поля «женское начало» свидетельствует присутствие сильного противоположного поля «мужское начало». Оппозиция мужское / женское обнаруживает в рамках системы явную динамику развития (в отличие, например, от выше рассмотренной оппозиции русское / иностранное), т.к. между «мужским началом» и «женским началом» устанавливаются отношения центр / периферия. Потому при отсутствии непосредственных связей в рамках системы они вступают в уже не мнимый (как русское / иностранное), а явный конфликт, который, конечно, носит структурно-семиотический характер и может впоследствии отразиться на организации всей литературно-эстетической системы (уже, видимо, другого периода).

Наименее значимые в исследуемой системе семантические связи (см. рисунок) доминантное поле «организация произведений» образует с периферийными полями, т.е. такими компонентами семиотической системы прозы 1840-х годов, которые утратили / еще не приобрели собственный 
семиотический вес, вследствие чего не имеют достаточной актуальности в рамках системы. Такого же типа зависимости доминанта формирует с тупиковыми компонентами, которые, как правило, указывают на границы системы, на факторы, по нашему мнению, разрушающие эволюционную непрерывность ее стадиальных переходов.

Тупиковые связи с «организацией произведений» образуют поля «универсализация», «семейные отношения» и «эмоционально-чувственные состояния». Поле «универсализация» составили семы, указывающие на обобщенность, охват большого количества предметов, явлений, событий, действий, личностей и т.П., на их повторяемость, типичность. Причем эти семы представляют собой именно силу, интенцию, способную перевести множественность единичных проявлений в типичность факта, события, образа безотносительно к их содержанию. Примерами таких обобщений может служить очевидное переосмысление конкретного явления, события, факта в качестве репрезентанта ряда подобных, что происходит в заглавиях «Двойная жизнь» (К.К. Павлова, 1848), «Противоречия» (М.Е. Салтыков-Щедрин, 1847) и т.п. Процесс универсализации затрагивает и человеческие личности («Мои курские знакомцы» (М.С. Жукова, 1840)), а также позволяет переносить закономерности, присущие одному миру в качественно иной, чтобы указать на подчинение всех и вся некоторым универсальным законам («Позументы» (Н.В. Кукольник, 1842) перенос законов мира вещей на мир людей).

Связь «универсализации» только с «организацией произведения» (хотя в это время с подачи «натуральной школы» было «модно» создавать социальные, психологические, национальные типы) говорит о том, что она приобрела самостоятельность как структурирующий принцип и в данном качестве обнаружила границы цельности существующей семиотической системы. Стремление к универсализации, так или иначе, было свойственно и предшествующим эпохам, однако, очевидно, реалистическая типизация доводит приемы универсализации до конструктивного логического конца, дальнейшая их эксплуатация не оставляет места неповторимой человеческой индивидуальности, т.е. разрушает изнутри собственные гуманистические основания, и приводит к разрыву в поступательном развитии системы.

Связи с полями «семейные отношения» и «эмоционально-чувственные состояния〉 имеют статус тупиковых по сходным причинам, но они, кроме всего прочего, отражают изменяющиеся в обществе взгляды на семейные ценности и на эмоционально-чувственную сферу. Компоненты поля «семейные отношения» мы выделяли в заглавиях «Хозяйка» (Ф.М. Достоевский, 1847) (одно из значений этого слова - «жена»), «Привидение первого мужа, или Вдова замужем» (И.П. Клюшников, 1841) и т.П. Семы, выражающие чувства и эмоции, открываются и через непосредственное указание на эмоциональное состояние или чувство («Бедные люди» (Ф.М. Достоевский, 1846) - сочувствие; «Горюн» (Я.П. Бутков, 1847) - горе), и через словообразовательные средства, выражающие эмоции («Маленький герой» (Ф.М. Достоевский, 1849); «Маменькин сынок» (И.И. Панаев, 1845)), и через слова, предполагающие ситуацию, сопровождающуюся определенным эмоциональным состоянием («Ярмарка» (Г.Ф. Квитка, 1840 - 1842) - ярмарочное веселье; «Приезжий из уезда, или Суматоха в столице» (А.Ф. Вельтман, 1841) - суматоха).

Семейные отношения уже в 40-е годы XIX века начинают переосмысляться, равно как, видимо, и принятая шкала эмоциональности и степени переживания чувств. Потому семейная тема и область эмоционально-чувственных состояний тоже становятся граничными составляющими семиотической системы включение данных проблем в пространство произведения способствует окончательному их «изживанию» и ведет либо к качественному скачку системы - 
через художественную профанацию и разрушение указанных семиотических компонентов, - либо к вторичности создаваемого по прежним канонам произведения.

Периферийные поля, соотнесенные с доминантой наименьшей по значимости связью, как мы уже отмечали, имеют потенциальную актуальность для системы. «Литературные приемы», «межличностно-коммуникативные отношения», «официальная сфера» и «историческое время» - та семиотическая база, которая обеспечивает системе связь с прошлым и с будущим (из уже рассмотренных полей к периферии относятся «русская историко-культурная среда», «иностранная историко-культурная среда», «женское начало»). Поле «литературные приемы» составили речевые характеристики, риторические приемы, стилистические каламбуры и т.п. Так, заглавие «Кредиторы, любовь и заглавия» (Я.П. Бутков, 1847) строится на основе алогизма (зевгмы), объединяющего в качестве однородных членов предложения разнокачественные понятия, что способствует комическому эффекту, а также увеличению ощущения абсурдности, проецируемому на создаваемый художественный мир. В «Знакомых незнакомцах» (Г.Ф. Квитка, 1840 - 1842) посредством оксюморона создается эффект обобщения, типизации образов; в «Рассказе Алексея Дмитрича» (А.В. Дружинин, 1848) разговорное «Дмитрич» служит характеристике персонажа и всей коммуникативной ситуации; и т.п.

Соотнесение данного периферийного поля с доминантой указывает на устанавливающиеся в художественной действительности аналогии между эстетической организацией речи с помощью специальных приемов и организацией пространства произведения. В этом контексте самостоятельный статус поля «литературные приемы» свидетельствует о появлении в системе прозы 1840-х годов стремления рефлектировать над словесной реальностью языковыми средствами, художественный мир становится пространством жизни, развития, саморефлексии языковых приемов.

Компоненты поля «межличностно-коммуникативные отношения» предполагают акцентирование на целостной коммуникативной ситуации, включающей факт межличностного взаимодействия, речевой акт и обязательную вовлеченность коммуникантов в ценностное пространство друг друга. Так, целые коммуникативные ситуации, предполагающие присутствие и даже активное участие общающихся, воссоздаются в заглавиях «Чужая голова - темный лес» (Е.П. Гребенка, 1845 - 1848), «Завещание дяди племяннику» (А.Н. Майков, 1847), «Званый вечер» (Г.Ф. Квитка, 1840 - 1842) и т.п. На наш взгляд, потенциальность данного поля в контексте общего семиотического процесса интересующего нас периода заключается в открывающейся установке на диалогичность, в положительной или отрицательной направленности на другого. Установка на диалогичность в 40-х годов XIX века начинает приобретать онтологический статус.

Еще одно периферийное поле, призванное отразить некоторые особенности художественной онтологии изучаемого десятилетия, - «официальная сфера». Составляющие данное периферийное поле компоненты актуализируют принципы деления общества по чинам, по военным званиям, отношения власти / подчинения в рамках официально-делового пространства. Несомненное присутствие семантических компонентов данного поля можно отметить в заглавиях «Русские полководцы» (Н.А. Полевой, 1845), «Опыт истории Государственного совета в России с 1769 по 1820 г.» (В.И. Туманский, 1841), «Официальный обед» (М.Н. Загоскин, 1841). Потенциал поля «официальная сфера» заключается в том, что, становясь одним из принципов организации произведения (связь с доминантой), данное поле преображается из фонового компонента в активную силу, вступающую в конкуренцию с человекоцентрическим принципом 
организации художественного мира, актуальным на данном этапе развития системы (мир чинов, «поглощающий» человеческую личность, - один из распространенных символических «персонажей» литературы последующих эпох).

Последнюю нерассмотренную связь ядро культурно-семиотической системы прозаических произведений 40-х годов XIX века образует с периферийным полем «историческое время». В это поле вошли семы, указывающие на конкретный период в мировой истории - в древности или современности - а также на факт смены исторических эпох («Генерал Калимерос» (А.Ф. Вельтман, 1840), «Кузьма Петрович Мирошев, русская быль времен Екатерины ІІ» (М.Н. Загоскин, 1842)). Незначительная встречаемость «исторического времени», а также его слабая связь с «организацией произведения» есть свидетельство лишь фоновой задействованности данного периферийного поля в процессе организации художественных миров и его латентной потенциальности в контексте семиотический системы прозы 1840-х годов. На наш взгляд, причины деактуализации поля «историческое время» заключаются в кардинально переменившихся эпохальных представлениях о времени вообще (его знаках, его течении) и в переориентировке на пространственное по преимуществу мировидение. В частности, наблюдается отчетливая тенденция подчинения временных параметров национально-культурным («Ольга. Быт русских дворян в начале нынешнего столетия» (Д.Н. Бегичев, 1840), «Русские ночи» (В.Ф. Одоевский, 1844)) и пространственным («Брынский лес. Эпизод из первых годов царствования Петра Великого» (М.Н. Загоскин, 1846), «1812 год в провинции» (Г.Ф. Квитка, 1843) и т.п.

Таким образом, пространство прозы 40-х годов XIX века можно представить в качестве неоднородного иерархически организованного единства, специфические особенности которого обусловлены тенденцией к формированию принципов новой художественной онтологии. Наиболее значимыми онтологическими принципами этого периода становятся личностное, означенное (семантизированное) собственным именем пространство героя, социальная идентификация и принципиальная «мужскость», которые задают развитие всей повествовательной структуры. Важными для художественной онтологии 1840-х годов оказываются также принципы, утверждающие художественнолитературную природу произведения, указывающие на процесс писания и идентификации в мире литературных форм, на культурные контексты, необходимые для организации и понимания художественного мира, на аксиологическую позицию автора и / или рассказчика по отношению к создаваемой реальности.

Очевидному переосмыслению в рассмотренное время подверглось соотношение онтологических категорий времени и пространства. Бытийственные конфликты, связанные с течением времени (в том числе, исторического времени человечества) уходят на второй план, что характерно для ситуации зарождения новой онтологии, точки мифоонтологического первотворения, в которой времени как движущейся и движущей силы еще нет, оно находится в синтетическом единстве с пространством, только начинающим первичную дифференциацию. Потому в контексте 1840-х годов объяснимо выдвижение пространства в качестве одного из важных концептуальных блоков семиотической системы, причем значимостью в ней обладают именно универсальные характеристики пространства («новое небо и новая земля»), востребованные в период любого онтологического переустройства. Логичным оказывается и фоновый статус специфически русских и подчеркнуто иностранных культурных маркеров: четкое разделение национальных культурных особенностей, равно как и акцентуация на временной и / или пространственной конкретике, по нашему мнению, есть 
реликты предшествовавшего состояния системы, переход же к новому качеству сопровождается образованием первичных онтологических единств.

Среди второстепенных семиотических тенденций эпохи обнаружились такие, которые, на наш взгляд, указывают на возможные будущие сценарии изменения культурно-семиотической системы 40-х годов XIX века. Явная динамика открывается в связи с пониманием центральных координат человеческого бытия. Так, кардинальной трансформации, способной переориентировать ценностноэстетические установки всей семиотической системы, начинают подвергаться семейные отношения, сфера чувств и эмоций (способы их выражения, деление по аксиологическому принципу и т.п.), основания, виды, цели и следствия универсализации и типизации явлений, событий, личностей. Вместе с тем, значительное место в системе онтологии человека теперь занимает его официальный статус, приобретающий самостоятельность и вступающий с личностным началом в активную борьбу за идеологическое, семиотическое и онтологическое первенство. Кроме того, постепенно усиливают влияние на систему гендерные характеристики, открывающие дополнительные контексты для развития процесса эпохального семиозиса.

\section{Литература}

Белоусов К.И., Зелянская Н.Л. «Как в сердце русском отзовется...» (лингвомаркетологическое исследование концепта «водка») // Russian Food and Drinks market magazine. 2005a. № 6-7 (70-71).

Белоусов К.И., Зелянская Н.Л. Графосемантическое моделирование концептуальной организации текста // Художественный текст: варианты интерпретации. Труды межвузовской научно-практической конференции (Бийск 16-17 мая): В 2 ч. Бийск, 2005б. Вып. 10. Ч. 2.

Белоусов К.И., Зелянская Н.Л. Применение метода графосемантического моделирования в лингвомаркетологических исследованиях // Вестник Оренбургского государственного университета. 2005в. № 8.

Выготский Л.С. Психология искусства. Ростов н/Д., 1998.

Гласс Дж., Стэнли Дж. Статистические методы в педагогике и психологии. M., 1976.

Зелянская Н.Л. Аксиологическая и гносеологическая активность литературоведческих категорий в пространстве рецепции (экспериментальный аспект) // Вестник Оренбургского государственного университета. 2005а. № 11.

Зелянская Н.Л. Образ классика как становящийся феномен (к проблеме механизмов культурной деривации) // Актуальные проблемы современного словообразования. Труды Международной научной конференции. Томск, 20056.

Зелянская Н.Л. Филологическая рецепция литературного факта: экспериментальное изучение и моделирование // Квантитативная лингвистика: исследования и модели (КЛИМ - 2005): Материалы Всероссийской научной конференции (6-10 июня 2005 г.). Новосибирск, 2005в.

Зелянская Н.Л., Белоусов К.И. Культурогенность как принцип структурирования смыслового пространства художественного текста // Вестник Оренбургского государственного университета. 2006. № 11.

Лакин Г.Ф. Биометрия. М., 1980.

Русские писатели. Биобиблиографический словарь: В 2 ч. М., 1990.

Тюпа В.И. Аналитика художественного (введение в литературоведческий анализ). М., 2001.

Штоф В.А. Моделирование и философия. М.; Л., 1966. 